\title{
Latest Interative Larning Devices Available in Rural Schools
}

\author{
J.Kannan, D. Venkatrama Raju
}

\begin{abstract}
Education plays an vital role in any country's development, improving the economy of that country, improving people's living standards, etc. In higher education, it is even more necessary as the higher education produces all the professionals. Each country is trying to develop such institutions that produce high-quality professionals in all fields. India is a developing country and is also focused on developing its people in terms of their living standards by providing more and more education through the establishment of educational institutions, especially higher education institutions. The number of higher education institutions in India has increased in last few years, as well as the enrollment in these institutions has increased very much.
\end{abstract}

Keywords - Economy, Educational Institutions.

\section{INTRODUCTION}

India is a developing country and is also focused on developing its people in terms of their living standards by providing more and more education through the establishment of educational institutions, especially higher education institutions. In the late 19th and early 20th centuries, public education spending ranged significantly across regions with the western and southern provinces spending three to four times as much as the eastern provinces[1]-[5]. Because of historical differences in land taxes, much of the inter-regional difference was the main source of income. Lord Curzon, the Viceroy 1899-1905, gave high priority to mass education after finding that no more than 20 percent of India's children attended school. His initiatives centered on the development in education and the modernization of university systems. They stressed ungraded curricula, traditional textbooks, and new systems of evaluation. Curzon's technical education plans laid the foundations on which later governments took action.

\section{OBJECTIVES}

To understand the students and parents problems face while studied government school -Kanchipuram district

To study the parents satisfaction level towards government school educations - Kanchipuram district

Revised Manuscript Received on December 11, 2019

J. Kannan, Department of Science and Humanities, Bharath Institute of Higher Education and Research, Chennai, India. Email: sjkannan1986@gmail.com

D. Venkatrama Raju, Department of Science and Humanities, Bharath Institute of Higher Education and Research, Chennai, India. Email: prof.dvraju@gmail.com
To get valuable suggestions for improving government school performance[6]-[9]

\section{RESEARCH METHODOLOGY}

The methods may include research on journals, interviews, surveys and other research techniques, and may include both current and historical data[10]-[12].

\section{A. Research Design}

The work uses the form of descriptive analysis. Descriptive research's main purpose is to describe the state of affairs as it currently exists. To make a critical evaluation of the content, the details and information collected are evaluated.

\section{B. Sampling Unit}

The study mainly based on convenience method for the purpose of out of 100 respondents in Kanchipuram district.

\section{Tool Used for Analysis}

Simple percentage method, Chi-square test, Rank analysis and Karl Pearson's correlation coefficient[13]-[17].

\section{Limitatations}

The Study is limited to Kanchipuram town and therefore the findings of the study cannot be extended to other area

The samples have been collected from the limited member (sample size 100) of Rural parents

\section{RESULTS AND DISCUSSION}

$\square(41.7 \%)$ age group of $36-45$ years.

$\square(37.7 \%)$ were educated till school level.

$\square(28.6 \%)$ parents were agriculturist.

$\square(44.6 \%)$ parents were having two children.

$\square(30.3 \%)$ monthly income were Rs. 10000 to 12500

$\square(47.4 \%)$ select a school through family members.

$\square(33.1 \%)$ husband and wife are taking their decision for selecting and join the school.

$\square(37.7 \%)$ children studying ninth class .

$\square(39.4 \%)$ children were studied same school 6 to 7 years.

$\square$ mean value (2.46) with the age group of above 45 years are highly satisfied towards their children current performance, it is found that

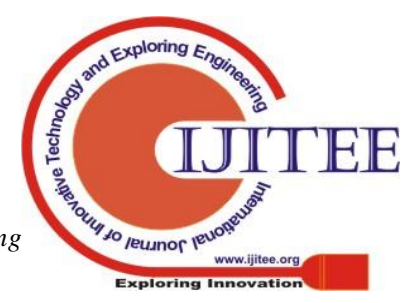




\section{Latest Interative Larning Devices Available in Rural Schools}

there is a close significant relationship between the age of the respondents and the level of satisfaction of children current performance.

$\square$ mean value (2.90) with the age group of 36-45 years are highly satisfied towards their school management, it is found that there is a close significant relationship between the age of the respondents and the level of satisfaction of school management[18]-[20].

$\square$ mean value (2.36) with the qualified of school level and under graduate and highly satisfied towards quality of education that there is no relationship between the educational status of the respondents and level of satisfaction in quality of education.

$\square$ mean value (3.31) of the illiterate respondents are highly satisfied towards their school management there is a close significant relationship between the education of the respondents and the level of satisfaction of school

$\square$ mean value (2.91) were businessmen and they are highly satisfied towards their communication of the school there is a close significant relationship between the occupation of the respondents and the level of satisfaction of communication from the school[21]-[23].

$\square$ mean value (3.55) monthly income 15000 and highly satisfied towards their infrastructure of the school there is a close relationship between the monthly income of the respondents and the level of satisfaction of infrastructure of the school.

$\square$ mean value (3.09) monthly income as Rs.12500 to15000 and highly satisfied towards their school management there is no significant relationship between the monthly income of the respondents and level of satisfaction of school management.

$\square(55.4 \%)$ parents were preferred the government school for less fees.

$\square(50.3 \%)$ parents considered very important factor of academic results in the school.

$\square(74.3 \%)$ received scholarships from the government. government school.

$\square(55.4 \%)$ satisfied in teachers activities.

$\square(65.7 \%)$ parents satisfied the quality of education in government school.

$\square(40.0 \%)$ parents dissatisfied towards the government school infrastructure.

$\square(34.3 \%)$ satisfied in management of government school.

$\square(44.0 \%)$ neutrally satisfied proper communication from the school.

$\square(53.7 \%)$ parents are highly satisfied in government school regarding sports and co-curricular activities.

$\square(77.7 \%)$ school providing the free stuff based on government rule.

$\square(84.6 \%)$ opined fees not collected from the government school.

$\square(72.0 \%)$ not interested to change the children school in near future.

$\square(68.6 \%)$ parents willing to recommend - others children. $\square$ children are facing the problem as 'lake of car' and 'quality of the teaching' while going to current school. management.

$\square(56.0 \%)$ satisfied in their children performance in

\section{SUGGESTIONS}

Children should be helped by their parents in their daily needs (textbooks, workbooks, pens, pencils, satchels, etc.). Government can also provide the poor children with educational and learning services to reduce the pressure on poor families from educational expenses.

The involvement of parents in their family / social enmity should be avoided. It helps to increase the academic performance of their children.

Steps should be taken to raise awareness in the community of the importance of the involvement of rural parents in the education of their children[24]-[25].

The creation of government school teachers must find an important issue to improve the quality of education and draw more parents to government schools.

\section{CONCLUSION}

The result stated that in terms of curriculum, teacher quality, and school policies, the program in government school is inferior to private schools. It provides the answer to the research's key questions about the increasing number of students studying in private schools Parents have expressed their desire to teach English language skills in government schools. In addition, a government school's quality of teachers influenced the overall value of the education system. Teachers in government schools felt the schools did not give them adequate training to improve their attitude. Most educators faced a lack of training for professional education that meets their needs. The private schools, on the other hand, tried to satisfy the desires and needs of the students. To improve their quality and enhance the degree of excellence at government schools, teachers are provided with a development plan.

\section{REFERENCES}

1) Vasanthi, S. \& Rabiyathul Basariya, S. 2019, "Influence of value analysis and cross training in industry", International Journal of Engineering and Advanced Technology, vol. 8, no. 6, pp. 1810-1811.

2) Velvizhi, R., Sri Gowtham, S. \& Jeya Priya, D. 2019, "Examination of early feedbacks for effective product retailing on E-commerce websites", International Journal of Engineering and Advanced Technology, vol. 8, no. 6 Special Issue 2, pp. 703-706.

3) Anuradha, C., Pothumani, S. \& Kavitha, R. 2019, "A novel method towards E-commerce", International Journal of Engineering and Advanced Technology, vol. 8, no. 6 Special Issue 2, pp. 535-538.

4) Thomas, J. \& Rabiyathul Basariya, S. 2019, "A study on the issues of financial ratio analysis", Indian Journal of Public Health Research and Development, vol. 10, no. 3, pp. 1079-1081.

5) Ramachandran, S. \& Rabiyathul Basariya, S. 2019, "Online marketing study on customer satisfaction and relationship", Indian Journal of Public Health Research and Development, vol. 10, no. 3, pp. 1072-1078.

6) Priya, R., Vinothini, G. \& Cor Jesu, C.D. 2019, "The mentor-protégé relationship for professional growth", Journal of Advanced Research in Dynamical and Control Systems, vol. 11, no. 9 Special Issue, pp. 1110-1119.

7) Jannifer Rani, N., Bina Pani, S. \& Nimisha, N.S. 2019, "A study on money back polices available in LIC", Journal of Advanced Research in Dynamical and Control Systems, vol. 11, no. 9 Special Issue, pp. 833-839.

8) Saillaja, V., Jhansi Rani, K. \& Catherine, R. 2019, "Global marketing management planning and organization", Journal of Advanced Research in Dynamical 
and Control Systems, vol. 11, no. 9 Special Issue, pp. 489-493.

9) Saillaja, V., Jhansi Rani, K. \& Catherine, R. 2019, "The new phase of marketing information system", Journal of Advanced Research in Dynamical and Control Systems, vol. 11, no. 9 Special Issue, pp. 482-488.

10) Thoufiqulla \& Raju, D.V. 2019, "Perception of indian investor towards investment in mutual funds with special reference to mip funds", Journal of Advanced Research in Dynamical and Control Systems, vol. 11, no. 5, pp. 177-183.

11) Jasmine, K.R.M. \& Basariya, S.R. 2018, "A study on the customers benefits on mutual funds", International Journal of Civil Engineering and Technology, vol. 9, no. 4, pp. 45-48.

12) Vasanthi, S. \& Basariya, S.R. 2019, "Pros and cons of on the job training versus off the job training", International Journal of Scientific and Technology Research, vol. 8, no. 10, pp. 671-674.

13) Pavithra, J. \& Ganesan, M. 2016, "A study on awareness and impact of micro-financial schemes", International Journal of Applied Business and Economic Research, vol. 14, no. 8, pp. 5449-5460.

14) Pavithra, J., Dilli Babu, P. \& Ambuli, T.V. 2014, "A study on budgetary control at Maruti Service Masters, Chennai", International Journal of Applied Business and Economic Research, vol. 12, no. 2, pp. 151-161.

15) Gunaraja, T.M. \& Venkatrama Raju, D. 2018, "Determining factors of organisational climate with reference to leadership styles", International Journal of Mechanical Engineering and Technology, vol. 9, no. 9, pp. 1327-1332.

16) Gunaraja, T.M. \& Venkatrama Raju, D. 2018, "The role of job satisfaction and training of employees in determining organisational climate of a selected industry", International Journal of Civil Engineering and Technology, vol. 9, no. 8, pp. 1266-1269.

17) Aarathy, T.S. \& Raju, D.V. 2018, "Performance appraisal and its effects on employees with respect to it sector in Chennai city", International Journal of Civil Engineering and Technology, vol. 9, no. 6, pp. 1535-1538.

18) Aarathy, T.S. \& Raju, D.V. 2018, "Employee perception towards performance appraisal system in IT sector", International Journal of Mechanical Engineering and Technology, vol. 9, no. 5, pp. 131-135.

19) Porselvi, W., Jublee, D. \& Sivanesan, G. 2018, "A study on factors influencing adoption of technology and innovation in banking industry, tamilnadu, India", International Journal of Mechanical Engineering and Technology, vol. 9, no. 5, pp. 789-800.

20) Akessa, G.M. and Dhufera, A.G., 2015. Factors That Influences Students Academic Performance: A Case of Rift Valley University, Jimma, Ethiopia. Journal of Education and Practice, 6(22), pp.55-63.

21) Miller, G. and Shih, C.C., 1999. A faculty assessment of the academic rigor of on-and off-campus courses in agriculture. Journal of Agricultural Education, 40, pp.57-65.

22) Tsinidou, M., Gerogiannis, V. and Fitsilis, P., 2010. Evaluation of the factors that determine quality in higher education: an empirical study. Quality Assurance in education, 18(3), pp.227-244.

23) Farooq, M.S., Chaudhry, A.H., Shafiq, M. and Berhanu, G., 2011. Factors affecting students' quality of academic performance: a case of secondary school level. Journal of quality and technology management, 7(2), pp.1-14.

24) Fitsilis, P., Gerogiannis, V. and Anthopoulos, L., 2014. Ontologies for software project management: a review. Journal of Software Engineering and Applications, 7(13), p.1096.

25) Adams, J.D. and Jaffe, A.B., 1996. Bounding the effects of R\&D: an investigation using matched establishment-firm data(No. w5544). National bureau of economic research.

\section{AUTHORS PROFILE}

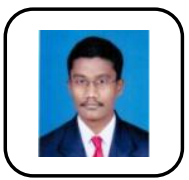

J. Kannan Associate Professor, Department of Science and Humanities, Bharath Institute of Higher Education and Research, Chennai, India.

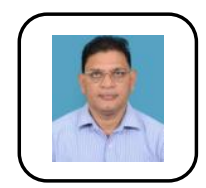

D. Venkatrama Raju Professor, Department of Science and Humanities, Bharath Institute of Higher Education and Research, Chennai, India. 